\title{
Brain injury markers (S100B and NSE) in chronic cocaine dependents
}

\section{Marcadores de lesão cerebral (S100B e NSE) em dependentes crônicos de cocaína}

\author{
Felix Henrique Paim Kessler, ${ }^{1}$ George Woody, ${ }^{2}$ \\ Luís Valmor Cruz Portela, ${ }^{3}$ Adriano Bretanha Lopes Tort, ${ }^{3}$ \\ Raquel De Boni, ${ }^{1}$ Ana Carolina Wolf Baldino Peuker, ${ }^{1}$ \\ Vanessa Genro, ${ }^{1}$ Lísia von Diemen, ${ }^{1}$ \\ Diogo Onofre Gomes de Souza, ${ }^{3}$ Flavio Pechansky ${ }^{1,4}$
}

\begin{abstract}
Objective: Studies have shown signs of brain damage caused by different mechanisms in cocaine users. The serum neuron specific enolase and S1OOB protein are considered specific biochemical markers of neuronal and glial cell injury. This study aimed at comparing blood levels of S1OOB and NSE in chronic cocaine users and in volunteers who did not use cocaine or other illicit drugs. Method: Twenty subjects dependent on cocaine but not on alcohol or marijuana, and 20 non-substance using controls were recruited. Subjects were selected by consecutive and non-probabilistic sampling. Neuron specific enolase and S100B levels were determined by luminescence assay. Results: Cocaine users had significantly higher scores than controls in all psychiatric dimensions of the SCL-90 and had cognitive deficits in the subtest cubes of WAIS and the word span. Mean serum S100B level was $0.09 \pm 0.04 \mu \mathrm{g} / \mathrm{l}$ among cocaine users and $0.08 \pm 0.04 \mu \mathrm{g} / \mathrm{l}$ among controls. Mean serum neuron specific enolase level was $9.7 \pm 3.5 \mathrm{ng} / \mathrm{l}$ among cocaine users and $8.3 \pm 2.6 \mathrm{ng} / \mathrm{l}$ among controls. Conclusions: In this first study using these specific brain damage markers in cocaine users, serum levels of S100B and neuron specific enolase were not statistically different between cocaine dependent subjects and controls.
\end{abstract}

Descriptors: Cocaine; Cognitive science; Cognition disorders; Symptoms, psychotic; Neuron specific enolase

\begin{abstract}
Resumo
Objetivo: Estudos têm demonstrado sinais de lesão cerebral causadas por diferentes mecanismos em usuários de cocaína. A enolase sérica neurônio-específica e a proteína $S 100 B$ são consideradas marcadores bioquímicos específicos de lesão neuronal e glial. Este estudo objetivou comparar os níveis sangüíneos de S100B e enolase sérica neurônio-específica em usuários crônicos de cocaína e em voluntários que não usam cocaína ou outras drogas ilícitas. Método: Vinte sujeitos dependentes de cocaína, mas não dependentes de álcool, maconha ou outra droga, e 20 sujeitos controles não usuários de drogas foram recrutados. Os sujeitos foram selecionados por amostragem consecutiva e não-probabilística e os níveis de enolase neurônio-específica e S100B foram determinados por ensaio de luminescência. Resultados: Os usuários de cocaína tiveram escores significativamente maior que os controles em todas as dimensões psiquiátricas do SCL-90 e apresentaram prejuízos cognitivos no subteste cubos do WAIS e no

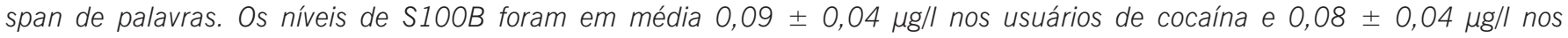
controles. Os níveis de enolase neurônio-específica foram em média 9,7 \pm 3,5 ng/l nos usuários e 8,3 \pm 2,6 ng/l nos controles. Conclusão: Neste primeiro estudo utilizando esses marcadores específicos de lesão cerebral em usuários de cocaína, os níveis séricos de $S 100 B$ e enolase especifica do neurônio não foram significativamente diferentes entre dependentes de cocaína e controles.
\end{abstract}

Descritores: Cocaína; Ciência cognitiva; Transtornos cognitivos; Sintomas psíquicos; Enolase neurônio-específica

\footnotetext{
1 Center for Drug and Alcohol Research, Universidade Federal do Rio Grande do Sul (UFRGS), Porto Alegre (RS), Brazil

2 Treatment Research Institute, School of Medicine, University of Pennsylvania, Philadelphia (PA), USA

3 Department of Biochemistry, Universidade Federal do Rio Grande do Sul (UFRGS), Porto Alegre (RS), Brazil

4 Department of Psychiatry and Legal Medicine, Universidade Federal do Rio Grande do Sul (UFRGS), Porto Alegre (RS), Brazil
}

Financing: Supported by Fundo de Incentivo à Pesquisa (FIPE) of the Clinical Hospital of Porto Alegre; by NIDA grants U10-DA 13043 and K05-DA 17009; and the Department of Veterans Affairs. Conflict of interests: None

Submitted: April 17, 2006

Accepted: August 1, 2006
Correspondence

Felix Henrique Paim Kessler

R. Itaqui, 89/103

90460-140 Porto Alegre, RS, Brazil

Phone/Fax: (55 51) 3332-8172

E-mail: kessler.ez@terra.com.br 


\section{Introduction}

The Brazilian Center of Psychoactive Drug Information ${ }^{1}$ has reported an increase in cocaine use during the last decade. Cocaine has been the psychotropic drug mostly responsible for increasing hospital admission rates, going up from $0.8 \%$ of all admissions in 1998 , to $4.6 \%$ in 1999 . The first household survey on use of psychotropic drugs in Brazil demonstrated that the overall prevalence of cocaine use was $2.3 \%$, whereas in the southern region this percentage was $3.6 \%$, the highest in the country. ${ }^{2}$

Cocaine dependence is seldom isolated from other psychiatric disorders. Community studies conducted in the U.S., such as the National Comorbidity Study, ${ }^{3}$ showed high levels of psychiatric comorbidity in persons with substance use disorders, particularly those using cocaine. Seventy six percent of cocaine users had additional psychiatric disorders. This level was much higher than that found in the general population, and twice as high as persons with alcohol dependence and four times higher than persons dependent on other drugs.

Cocaine is one of the illicit drugs that often impair neurological and neurobehavioral functions. Frequent and chronic users suffer the greatest risk of impairment. ${ }^{4}$ Animal research has shown that cocaine promotes degenerative alterations in neurons, as well as modifying receptor function and the production and release of dopamine and serotonin. However, the neurochemical and vascular processes involved in this apparent neurotoxicity are not yet clear. ${ }^{5-6}$

Cognitive deficits in cocaine users have been studied for the last twenty years. The main problems detected have been memory deficits and diminished performance ${ }^{7}$ in tests of calculation, visual-motor dexterity and abstraction ability. ${ }^{8-9}$ Other studies evaluated alterations in neuronal function using neuroimaging in persons who met DSM-IV criteria for cocaine dependence. ${ }^{10-11}$ They found a reduction in glucose metabolism and blood flow in many regions of the brain, particularly when cocaine use was associated with alcohol. Imaging studies of chronic users also found decreases in dopamine release and D2 receptors in the striatum. These changes were associated with reduced neuronal activity in the orbitofrontal cortex and cingulate gyrus, and with decreases in inhibitory control and increased impulsivity and compulsive behaviors. ${ }^{12-13}$ Franklin et al. ${ }^{14}$ found that the brain of cocaine-abusing patients is structurally altered with a decrease in gray matter in the orbitofrontal cortex, a region involved in decision-making and assignation of emotional valence to environmental stimuli.

In the last few years, neuronal damage has also been studied by examining alterations in substances found within the Central Nervous System (CNS). These have included lactate, adenylate kinase, creatine kinase isoenzyme BB (CK-BB), and $\mathrm{S} 100 \mathrm{~B}$ as well as neuron-specific enolase (NSE). The latter two proteins are considered to be the most important markers of damage to glial and neuronal cells respectively, and can be measured in the blood. ${ }^{15-17}$

$\mathrm{S} 100 \mathrm{~B}$ is a calcium-binding protein mostly produced and released by glial cells, where it exerts neurotrophic and gliotrophic actions. ${ }^{18}$ Several studies have been conducted to investigate its role as a marker of neuronal injury, possibly involving reactive gliosis, astrocytic death and/or blood-brainbarrier dysfunction. Accordingly, elevated cerebrospinal fluid (CSF) and/or serum S100B levels were found in patients with traumatic brain injury, ${ }^{19}$ stroke, Alzheimer's disease, ${ }^{20}$ schizophrenia, ${ }^{21}$ and HTLV-I associated myelopathy. ${ }^{22}$ Some studies suggest that alterations associated with cellular damage are higher in the first hours and days following acute damage. ${ }^{23}$ Neuron-specific enolase (NSE) is a cytoplasmic glycolytic enzyme, whose isoform is found in neurons and in cells with neuroendocrine differentiation, as well as in tumors that originated from them such as melanomas. Since NSE is not physiologically secreted, an increase in its serum and CSF levels may signalize structural damage to neuronal cells, as has been reported in persons with traumatic brain injury ${ }^{24}$ and seizures. ${ }^{25}$

With this background in mind, the present study aimed at comparing cognitive performance and psychiatric symptoms in chronic cocaine users and in volunteers who did not use cocaine or other illicit drugs. Blood levels of S100B and NSE were measured to evaluate their potential value in detecting brain injury that may be associated with abnormalities in cognitive performance and psychiatric symptoms in persons with cocaine dependence.

\section{Method}

A case-matched cross-sectional study was conducted. Subjects were selected between February 2001 and September 2002 by means of newspaper advertisements and direct recruitment from two centers located in general hospitals (one at a University Hospital). Both centers had inpatient and outpatient clinics for drug treatment and patients were interviewed in the first week of admission.

Out of 73 cocaine users that were willing to participate in the study 20 subjects ranging from 18 to 50 years, dependent on cocaine but not on alcohol, marijuana or any other drug were selected. In order to be eligible for the study cocaineusing subjects should have been using cocaine for at least three years, meet DSM-IV criteria for current cocaine dependence, and have used cocaine at least once in the 45 days prior to the interview. This interval was selected because it is the maximum time during which recovery of cognitive deficits has been predicted to begin. ${ }^{26-27}$

Exclusion criteria were any other neurological or severe psychiatric illness (significant head injury, epilepsy, schizophrenia, bipolar disorder type I), use of antipsychotic or antidepressive drugs, meeting criteria for dependence on alcohol or other drugs (except for nicotine), and testing positive for HIV. These parameters were determined by clinical interview performed by treatment staff, and a questionnaire collected at study intake; urine tests were not requested. Most patients were interviewed during a weekend morning in order to not disturb their therapeutic activities.

Twenty healthy blood donors from the Clinical Hospital of Porto Alegre were matched by gender, age and years of study to the cocaine-dependent subjects. Similar exclusion criteria were applied to controls except for the fact that they needed to report no use of any illegal drug in the past year. All cocaineusing subjects and controls were tested for HIV, which is routine care for blood donors. One cocaine user was excluded due to a positive HIV test.

In the last decade, many questionnaires have been adapted to Portuguese in order to evaluate diagnosis and treatment in drug users. ${ }^{28-29}$ In this study, the instruments used were:

1) the Diagnostic Interview for Genetic Studies (DIGS); ${ }^{30}$

2) the SCL-90 - a structured interview administered by a trained researcher (FHPK) that assessed for substance use disorders according to DSM-IV and IDC-10 criteria; ${ }^{31}$

3 ) the Cocaine Assessment Profile (CAP), ${ }^{32}$ - an instrument that asks details about cocaine use and problems in social, professional, and family aspects of the individual's life; 
4) the Cocaine Addiction Severity Test (CAST) 32 - which consists of 38 questions and provides a score evaluating the severity of cocaine dependence

Cognitive performance was evaluated by a one-hour battery of neuropsychological tests composed of six subtests from the Revised Wechsler Adult Intelligence Scale (WAIS-R). These tests evaluates different areas of cognition: Similarities (logical and abstract thinking and verbal fluency), Vocabulary (verbal intelligence and semantic knowledge), Arithmetic (attention and memory) and Digit Span (immediate memory), Block Design (viso-spacial orientation and coordination),, ${ }^{33}$ as well as the Word Span test (concentration and stress tolerance). ${ }^{34}$

At the end of the interviews and neuropsychological testing, venous blood was collected in Vacutainer tubes with no anticoagulant added, centrifuged for serum separation, fractionated, and frozen at $-70^{\circ} \mathrm{C}$ until assay. Protein concentrations were measured by an immunoluminometric assay (LIA-mat, Sangtec 100), standardized in Brazil ${ }^{35}$ and found to be highly specific and sensitive. The Portela et al. group has published several studies relating brain diseases (Parkinson, Machado-Joseph Disease) with increased levels of S100B and NSE. ${ }^{36-37}$

The sample size was calculated based on results of previous studies with S100B and NSE that pointed to a minimum of $20 \%$ difference in their levels between cases and controls. The significance level was set at 0.05 , with $80 \%$ power, and the sample was calculated to have a minimum of 17 subjects in each group. General statistical analyses were based on comparisons between the main variables (demographics, cocaine use, psychiatric symptoms, cognitive performance and blood protein level) of the 20 cocaine-dependent subjects and their respective controls. For variables that did not show a normal distribution, the Wilcoxon Rank Sum test was used, and the Spearman test was used to obtain correlations. Analyses were performed using Statistical Package for the Social Sciences (SPSS) version 10.0.

The study was approved by the Institutional Review Board of the Clinical Hospital of Porto Alegre. All patients signed an informed consent explaining study procedures, including allowing research staff to know their HIV test result prior to entering the study.

Results

Subjects were well matched on demographic features, as seen in Table 1.

\section{Use of cocaine and other drugs}

The main results are described in Table 2. Among cocainedependent subjects, first use of cocaine ranged from 14 to 39 years. Forty-five percent had become cocaine dependent within 1 to 3 months after first use. The median weekly expenditure was approximately $U \$ 25$ and a gram cost around $\cup \$ 3$. Last cocaine use prior to entering the study ranged from 1 to 45 days with the median time of abstinence at 11 days since last use. The total score of the CAST scale - which ranges from 0 to 38, varied between 3 and 35, with a median of 25 . Most subjects consumed cocaine in the early evening (76\%) and/or late at night (57\%). Fiftyseven percent used cocaine in "missions" (throughout the entire night). Most subjects consumed it primarily while alone $(80 \%)$ and at home $(65 \%)$. Consumption with friends, at work, at parties or with spouses or sexual partners was less frequent.
Table 1 - Demographic data of cocaine users and matched controls

\begin{tabular}{|c|c|c|c|c|}
\hline \multirow[b]{2}{*}{ Gender } & \multirow{2}{*}{$\begin{array}{ll} & \text { p } \\
1 & \end{array}$} & \multicolumn{2}{|c|}{ Cases $n=20(\%)$} & \multirow{2}{*}{$\begin{array}{c}\begin{array}{c}\text { Controls } \\
\mathbf{n}=20(\%)\end{array} \\
17(85) \\
3(15)\end{array}$} \\
\hline & & $\begin{array}{l}\text { Male } \\
\text { Female }\end{array}$ & $\begin{array}{c}17(85) \\
3(15)\end{array}$ & \\
\hline Age (mean) & $0.940^{\prime}$ & & $31.6 \pm 6.3^{*}$ & $31.4 \pm 6.1^{*}$ \\
\hline Marital status & $0.490^{\prime \prime}$ & $\begin{array}{l}\text { Married } \\
\text { Single } \\
\text { Other }\end{array}$ & $\begin{array}{c}5(25) \\
13(65.0) \\
2(10)\end{array}$ & $\begin{array}{c}8(40) \\
10(50) \\
2(10)\end{array}$ \\
\hline Color & $0.220^{\prime \prime}$ & $\begin{array}{l}\text { White } \\
\text { Other }\end{array}$ & $\begin{array}{l}18(90) \\
2(10)\end{array}$ & $\begin{array}{c}19(95) \\
1(5)\end{array}$ \\
\hline Personal income & $0.394^{n}$ & $\begin{array}{l}1-5 \text { m.w. } \\
5 \text { or more m.w. }\end{array}$ & $\begin{array}{c}13(65) \\
4(20)\end{array}$ & $\begin{array}{c}11(55) \\
7(35)\end{array}$ \\
\hline $\begin{array}{l}\text { Years of } \\
\text { schooling }\end{array}$ & $0.811^{\prime \prime}$ & Up to 8 & $3(15)$ & $4(20)$ \\
\hline & & $\begin{array}{l}9 \text { to } 11 \\
12 \text { or more }\end{array}$ & $\begin{array}{c}11(55) \\
6(30)\end{array}$ & $\begin{array}{l}9(45) \\
7(35)\end{array}$ \\
\hline
\end{tabular}

* mean $\pm S D$

't Student test

" $\chi^{2}$ Pearson test

- Minimum Wage = U\$ 80

Many subjects reported having negative consequences in their life due to cocaine use, such as negative consequences in their relationships (85\%), decreased social activities (61\%), missed work days (76\%), or decreased productivity (67\%). Twenty-three percent of the drug users reported having been fired due to cocaine use, and $90 \%$ percent confirmed that drugs had affected their financial life. Thirty percent reported having participated in some illegal activity related to cocaine.

Ninety-five percent of the cocaine subjects mentioned having some type of physical complication due to cocaine use. Those most commonly reported were: running nose (95\%), decreased energy (75\%), sinusitis (55\%) and weight loss (55\%). They also described having current anxiety (75\%), fatigue (70\%), depression (65\%), and changes in appetite (60\%) and sleep $(45 \%)$. Forty percent of cocaine subjects reported paranoid symptoms and $30 \%$ had hallucinations or other psychotic symptoms associated with cocaine use. None met criteria for dependence on alcohol, marijuana or other drugs. Nonetheless, there was a statistically higher weekly consumption of alcohol in the cocaine group than in the controls, with $70 \%$ of the cocaine users reporting weekly alcohol use as compared to $30 \%$ of the controls ( $p=0.01$ ).

SCL-90 scores were higher in cocaine users than controls, with $p$ values $<0.01$ in all dimensions of the instrument. Among cocaine users, correlations between severity of dependence, time of use, frequency and quantity of cocaine,

Table 2 - Cocaine use profile

\begin{tabular}{lc}
\hline & $(\mathbf{n})$ total $=\mathbf{2 0}$ \\
\hline Age of first use & $21.7 \pm 6.4^{\star}$ \\
Years of cocaine use in life & $9.0^{\star \star}$ \\
Ever injected cocaine & $28.6 \%(6)$ \\
Ever used crack & $19.0 \%(4)$ \\
Form of cocaine use in the last year & \\
Snorted & $81.0 \%(17)$ \\
Smoked & $4.8 \%(1)$ \\
Injected & $14.3 \%(3)$ \\
Number of days per week using cocaine in the last year & $3.3 \pm 1.9^{*}$ \\
Amount of cocaine per week in the last year (grams) & $8.0^{* \star}$ \\
Dose of last use (grams) & $5.0^{\star *}$ \\
\hline * Mean \pm Standard deviation & \\
** Median &
\end{tabular}


SCL-90 dimensions and cognitive WAIS subtests were not significant. Two significant correlations were found when cocaine users were dichotomized by means of dependence severity: the cocaine group with higher dependence severity was more likely to have elevated scores on the SCL-90 scales for phobia $(R=0.5)$ and depressive symptoms $(R=0.7)$ than users with lower severity scores.

\section{Evaluation of cognitive performance}

The WAIS's subtests and Word span scores are shown in Figure 1. When cognitive performance between cocainedependent and control subjects was compared, a significant difference in the Block Design subtest $(p=0.02$; effect size $=0.57$ ) and in Word Span ( $p=0.05$; effect size $=0.57$ ) was found.

\section{Neurochemical parameters}

Results are showed in Figure 2. S100B levels were not different between cocaine-dependent subjects (mean $=0.09 \pm 0.04 \mu \mathrm{g} / \mathrm{l}$ ) and controls (mean $=0.08 \pm 0.04 \mu \mathrm{g} / \mathrm{l})(p=0.35)$, nor were NSE levels different for cocaine dependent subjects $($ mean $=9.7 \pm 3.5 \mathrm{ng} / \mathrm{l})$ and controls (mean $=8.3 \pm 2.6 \mathrm{ng} / \mathrm{l})$ $(p=0.090)$. NSE levels could not be detected by the method in three samples and they were excluded from the analysis. There was no correlation between levels of these proteins and any of the variables related to cocaine, cognitive testing or psychiatric symptoms.

\section{Discussion}

With the increment in cocaine consumption in our environment, there is an increased interest in evaluating neuropsychological symptoms associated with its use, in understanding their pathophysiology, and how long they last. This issue is of interest for physicians, patients and their families. Moreover, these findings may contribute to improving prevention and treatment of cocaine dependence.

Cocaine-dependent subjects in this sample were predominantly male, had low income and average schooling level. They had mean use of cocaine of approximately nine years, mostly by inhalation, the most common way cocaine is used in Brazil. ${ }^{38}$

Drug users showed an intense and frequent consumption of cocaine in the preceding year, and had been abstinent for approximately eleven days (median) prior to testing. Some studies suggest that recent and intense use of cocaine, with

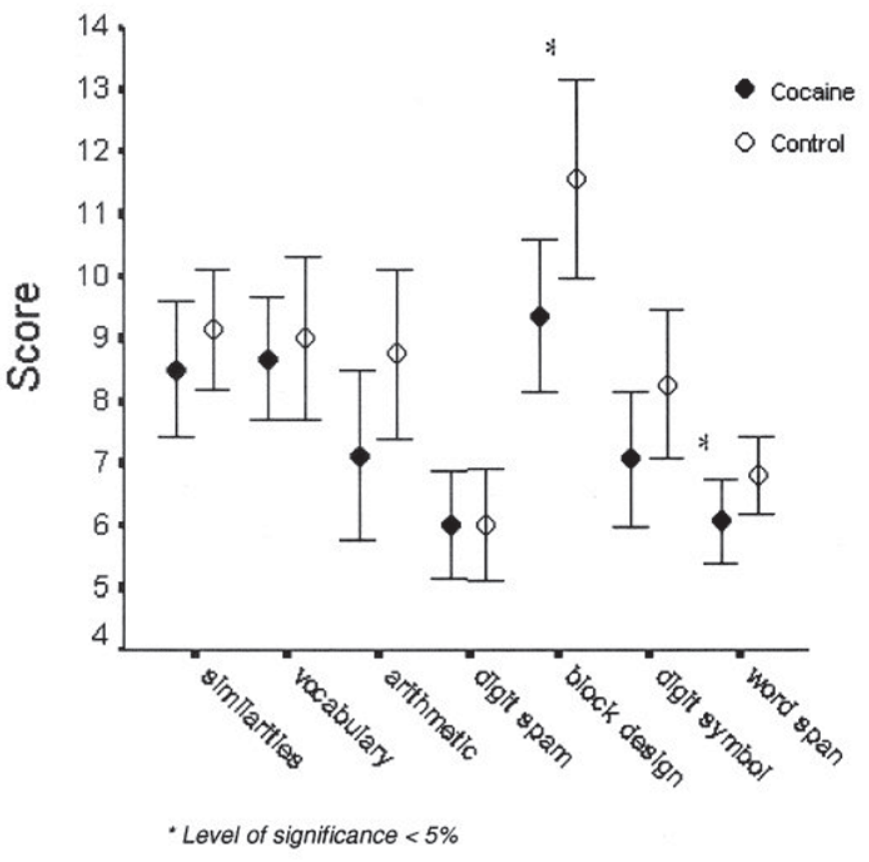

Figure 1 - Cognitive performance in WAIS-R subtests and Word Span

shorter periods of abstinence, is related to worse cognitive performance, particularly in areas affecting executive and learning functions, thereby directly impacting professional and other daily activities. .-9 $^{-9}$ Our results are consistent with these findings. Goldstein et al. concluded that compared to other psychiatric disorders (such as schizophrenia), the severity of neuropsychological impairment in cocaine addiction is modest. However, the impact of such small differences in cognitive performance on executive functions, learning abilities and quality of life may be substantial. ${ }^{39}$

With regard to cognitive testing, significant differences between groups in the WAIS-R Block Design subtest and Word Span were found. The Block Design test is affected almost exclusively by physiological alterations and depression, and is not impacted by sociocultural influences or education. However this data must be better investigated to be confirmed. ${ }^{33}$ Lower scores in the Word Span test among cocaine-dependent or depressive subjects indicate a deficit of immediate verbal memory. ${ }^{34}$ The
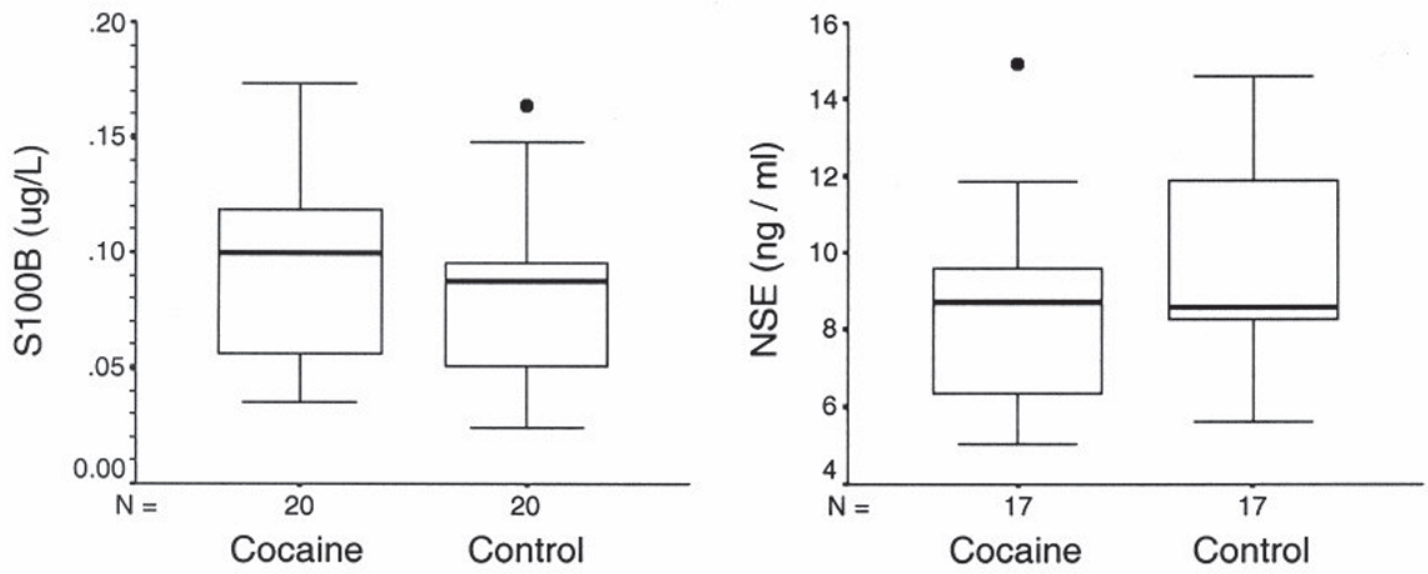

Figure 2 - Serum Levels of S100B e NSE 
fact that the Vocabulary subtest did not show significant differences between groups points to a homogeneity in relation to the past intellectual potential of the subjects since this subtest seems to be stable, not vulnerable to disturbances, and is used as a reference to estimate pre-morbid intelligence. In this sense, the differences between cocaine subjects and controls in both subtests point to cognitive deficits associated with long-term cocaine use, which is in agreement with previous studies. ${ }^{12,27,40-41}$ Nevertheless, all measures of psychiatric symptoms were significantly higher in cocaine subjects than in controls, sometimes due to drug use. Thus, cognitive deficits could also be caused by psychiatric symptoms or disorders.

This study is the first to evaluate serum levels of S100B and NSE proteins in cocaine users. Two previous animal studies involving $\mathrm{S} 100 \mathrm{~B}$ and prenatal cocaine exposure have been conducted, and it was shown that cocaine administration impaired the development of astroglial cells and diminished the distribution of S100B-positive astrocytes in the hippocampus and the cortex. ${ }^{42-43}$

In our study, despite the poorer performance in two of the cognitive tests and a high number of psychiatric symptoms in the cocaine group, serum levels of S100B and NSE were not statistically different from controls. Some hyphotheses could help explain these negative findings. The relation between these brain injury markers and neuropsychological performance is controversial. Some studies show a correlation between S100B levels and neuropsychological functions in patients with brain trauma and cardiac surgery. ${ }^{24,44-45}$ Other authors comment that there is no direct correlation between serum concentrations of S100B and cognitive function. ${ }^{46}$ We could also think that maybe cocaine use did not elicit large damage in the subjects, and their chronic cocaine use did not cause neurobiological and physiological injuries that could explain the cognitive deficits.

This study has some limitations - especially due to the number of subjects which made multivariate analyses difficult for other purposes than measuring the protein levels. However, the sample size was similar to other studies that measured these proteins. ${ }^{37,47}$ Another limitation is that in this crosssectional design we could not know the origin of psychiatric symptoms, particularly without a diagnostic history - as well as their influence in cognitive deficits. Another limitation is that unreported cocaine use among controls could have impaired our ability to find differences; this may be unlikely however, based on the evaluations that were performed at study intake, and the consistency of the findings between cocaine subjects and controls.

Chronic cocaine use can cause many kinds of alterations in brain function and morphology as it is presented in the introduction of this paper but the period of time after using cocaine that can damage cells and change the level of proteins is not known although S100B and NSE usually vary in the first hours in acute diseases. ${ }^{48}$ Other studies that evaluated psychiatric and neurological subjects have shown that in chronic disorders like schizophrenia and Alzheimer's Disease, S100B levels are mainly increased in the beginning of the disease or during its active phase. .1-22,49 $^{-1}$

The absence of glia and neuronal cellular damage, at least as reflected by these two markers, suggests that the pathophysiology underlying the cognitive and psychiatric symptoms associated with cocaine dependence are more likely to be originated from altered CNS plasticity processes (such as desensitization or sensitization of receptors, altered neural networks, or changes in neurotransmitters) than from chronic cellular damage. The fact that findings were negative in no way rules out the possibility that chronic cocaine use is associated with cellular damage within the CNS, especially during active cocaine use. Studies testing for these markers immediately after cocaine use, studies of other markers, and studies using animal models or cell culture should be conducted to further explore the brain damage associated with cocaine use.

Finally, the findings of this study suggest that these two neurochemical markers of brain damage were not associated with chronic cocaine use or the cognitive and psychiatric alterations in chronic cocaine users.

\section{Acknowledgments}

The authors are grateful to their colleagues in the Psychiatry and Biochemistry Department of UFRGS for their valuable input in the preparation of the manuscript, as well as to the research participants, the Blood Bank and the Laboratory of the Clinical Hospital of Porto Alegre.

\section{References}

1. Nappo SA, Noto AR, Galduroz JC, Carlini EA. Brazilian Center of Psychoactive Drug Information (CEBRID). 2000; Boletim no 44.

2. Carlini EA, Galduroz JC, Noto AR, Nappo AS. I Levantamento Domiciliar sobre o Uso de Drogas Psicotrópicas no Brasil: Estudo Envolvendo as 107 Maiores Cidades do País. Centro de Informações sobre Drogas Psicotrópicas (CEBRID) e Secretaria Nacional Antidrogas (SENAD). Cromosete Gráfica e Editora Ltda, São Paulo, Brasil; 2002.

3. Kessler RC, McGonagle KA, Zhao S, Nelson CB, Hughes M, Eshleman $\mathrm{S}$, Wittchen HU, Kendler KS. Lifetime and 12-month prevalence of DSM-III-R psychiatric disorders in the United States. Results from the National Comorbidity Survey. Arch Gen Psychiatry. 1994;51(1):8-19.

4. Strickland TL, Miller BL, Kowell A, Stein R. Neurobiology of cocaineinduced organic brain impairment: contributions from functional neuroimaging. Neuropsychol Rev. 1998;8(1):1-9.

5. Volpe F, Tavares A, Vargas A, Rocha P. Vasculite cerebral e uso de cocaína e crack. Rev Psiquiatr Clin. 1996;21(3):89-94

6. Nicastri S, Buchpiguel CA, Andrade AG. Anormalidades de fluxo sangüíneo cerebral em indivíduos dependentes de cocaína. Rev Bras Psiquiatr. 2000;22(2):42-50.

7. Cunha PJ, Nicastri S, Gomes LP, Moino RM, Peluso MA. Neuropsychological impairments in crack cocaine-dependent inpatients: preliminary findings. Rev Bras Psiquiatr. 2004;26(2): 103-6.

8. Jovanovski D, Erb S, Zakzanis KK. Neurocognitive deficits in cocaine users: a quantitative review of the evidence. J Clin Exp Neuropsychol. 2005;27(2): 189-204.

9. Selby MJ, Azrin RL. Neuropsychologycal functioning in drug abusers. Drug Alcohol Depend. 1998;50(1):39-45

10. Kosten TR. Pharmacotherapy of cerebral ischemia in cocaine dependence. Drug Alcohol Depend. 1998;49(2):133-44.

11. Nicastri S. Métodos de neuroimagem e abuso de substâncias psicoativas. Rev Bras Psiquiatr. 2001;23(1):28-31.

12. Bolla KI, Rothman R, Cadet JL. Dose-related neurobehavioral effects of cocaine use. J Neuropsychiatry Clin Neurosci. 1999;11(3):361-9.

13. Volkow ND, Fowler JS, Wang GJ, Swanson JM. Dopamine in drug abuse and addiction: results from imaging studies and treatment implication. Mol Psychiatry. 2004;9(6):557-69.

14. Franklin TR, Acton PD, Maldjian JA, Gray JD, Croft JR, Dackis CA, O'Brien CP, Childress AR. Decreased gray matter concentration in the insular, orbitofrontal, cingulate, and temporal cortices of cocaine patients. Biol Psychiatry. 2002;51(2):134-42. 
15. Johnsson P. Markers of cerebral ischemia after cardiac surgery. $J$ Cardiothorac Vasc Anesth. 1996;10(1):120-6.

16. Wunderlich MT, Wallesch CW, Goertler M. Release of neurobiochemical markers of brain damage is related to the neurovascular status on admission and the site of arterial occlusion in acute ischemic stroke. J Neurol Sci. 1996;227(1):49-53.

17. Ingebrigtsen $\mathrm{T}$, Romner B, Kongstad $\mathrm{P}$, Langbakk B. Increased serum concentrations of protein S-100 after minor head injury: a biochemical serum marker with prognostic value? J Neurol Neurosurg Psychiatry. 1995;59(1):103-4.

18. Donato R. S-100 proteins. Cell Calcium. 1986;7(3):123-45.

19. Ingebrigtsen $T$, Romner B. Biochemical serum markers for brain damage: a short review with emphasis on clinical utility in mild head injury. Restor Neurol Neurosci. 2003;21(3-4):171-6.

20. Sheng JG, Mrak RE, Rovnaghi CR, Kozlowska E, Van Eldik LJ, Griffin WS. Human brain S100 beta and S100 beta mRNA expression increases with age: pathogenic implications for Alzheimer's disease. Neurobiol Aging. 1996;17(3):359-63.

21. Lara DR, Gama CS, Belmonte-de-Abreu P, Portela LV, Goncalves CA, Fonseca M, Hauck S, Souza DO. Increased serum S100B protein in schizophrenia: a study in medication-free patients. J Psychiatr Res. 2001;35(1):11-4.

22. Walz R, Portela LV, Tort AB, Neto EC, Fernandes LN, Gonçalves CA, Souza D. Serum S100B levels in patients with HTLV-I associated myelopathy/tropical spastic paraparesis. Neurology. 2000;54(10):2021-2.

23. Chen DQ, Zhu LL. Dynamic change of serum protein S100b and its clinical significance in patients with traumatic brain injury. Chin $J$ Traumatol. 2005;8(4):245-8.

24. Herrmann M, Curio N, Jost S, Grubich C, Ebert AD, Fork ML, Synowitz $\mathrm{H}$. Release of biochemical markers of damage to neuronal and glial brain tissue is associated with short and long term neuropsychological outcome after traumatic brain injury. J Neurol Neurosurg Psychiatry. 2001;70(1):95-100.

25. Buttner T, Lack B, Jager M, Wunsche W, Kuhn W, Muller T, Przuntek $H$, Postert T. Serum levels of neuron-specific enolase and s-100 protein after single tonic-clonic seizures. J Neurol. 1999;246(6):459-61.

26. Kosten TR, Cheeves C, Palumbo J, Seibyl JP, Price LH, Woods SW. Regional cerebral blood flow during acute and chronic abstinence from combined cocaine-alcohol abuse. Drug Alcohol Depend. 1998;50(3): 187-95.

27. Smelson DA, Roy A, Santana S, Engelhart C. Neuropsychological deficits in withdrawn cocaine-dependent males. Am J Drug Alcohol Abuse. 1999;25(2):377-81.

28. Formigoni M, Castel S. Escalas de avaliação de dependência de drogas: aspectos gerais. Rev Psiq Clin. 1999;26(1):72-82.

29. Dinis M, Passos S, Camacho Luiz. Validade preditiva da versão em português da Escala do Desfecho Esperado do Tratamento em pacientes ambulatoriais dependentes de cocaína em um centro especializado. Rev Bras Psiquiatr. 2005;27(3):225-7.

30. Nurnberger JI, Blehar MD, Kaufmann CA, York-Cooler C, Simpson SG, Harkavy-Friedman J, Severe JB, Malaspina D, Reich T. Diagnostic Interview for Genetic Studies: rationale, unique features, and training. NIMH Genetics Initiative. Arch Gen Psychiatry. 1994:51(11):844-59.

31. Derogatis LR, Cleary PA. Factorial invariance across gender for the primary symptom dimensions of the SCL-90. Br J Soc Clin Psychol. 1977;16(4):347-56.

32. Washton AM. Cocaine addiction: treatment, recovery and relapse prevention. New York (NY): Ed. Norton; 1991.

33. Zimmerman IL. Woo-Sam JM. Interpretación Clínica de la Escala de Inteligencia Wechsler para Adultos (WAIS). 6a ed. Madrid: Tea Ediciones; 1995.

34. Miyake A. Individual differences in working memory: introduction to the special section. J Exp Psychol Gen. 2001;130(2):163-8.

35. Portela LV, Tort AB, Neto EC, Souza DO, Goncalves CA. Detection of S-100b protein in CSF, brain and serum of rats using a sensitive luminescence assay. Abstract. XXVII ${ }^{a}$ Reunião Anual da Sociedade Brasileira de Bioquímica e Biologia Molecular; 1998.

36. Schaf DV, Tort AB, Fricke D, Schestatsky P, Portela LV, Souza DO Rieder CR. S100B and NSE serum levels in patients with Parkinson's disease. Parkinsonism Relat Disord. 2005;11(1):39-43.
37. Tort AB, Portela LV, Rockenbach IC, Monte TL, Pereira ML, Souza DO, Rieder CR, Jardim LB. S100B and NSE serum concentrations in Machado Joseph disease. Clin Chim Acta. 2005;351(1-2):143-8.

38. Dunn J, Laranjeira R. Transitions in the route of cocaine administration - characteristics, direction and associated variables. Addiction. 1999;94(6):813-24.

39. Goldstein RZ, Leskovjan AC, Hoff AL, Hitzemann R, Bashan F, Khalsa SS, Wang GJ, Fowler JS, Volkow ND. Severity of neuropsychological impairment in cocaine and alcohol addiction: association with metabolism in the prefrontal cortex. Neuropsychologia. 2004;42(11):1447-58.

40. Strickland TL, Mena I, Villanueva-Meyer J, Miller BL, Cummings J, Mehringer CM, Satz P, Myers H. Cerebral perfusion and neuropsychological consequences of chronic cocaine use. J Neuropsychiatry Clin Neurosci. 1993;5(4):419-27.

41. Ardila A, Rosseli M, Strumwasser S. Neuropsychological deficits in chronic cocaine abusers. J Neurosci. 1991;57(1-2):73-9.

42. Akbari HM, Whitaker-Azmitia PM, Azmitia EC. Prenatal cocaine decreases the trophic factor S-100 beta and induced microcephaly: reversal by postnatal 5-HT1A receptor agonist. Neurosci Lett. 1994;170(1):141-4. Erratum in: Neurosci Lett. 1994:175(1-2): 176.

43. Clarke C, Clarke K, Muneyyirci J, Azmitia E, Whitaker-Azmitia PM. Prenatal cocaine delays astroglial maturation: immunodensitometry shows increased markers of immaturity (vimentin and GAP-43) and decreased proliferation and production of the growth factor S100. Brain Res Dev Brain Res. 1996;91(2):268-73.

44. Linstedt U, Meyer O, Kropp P, Berkau A, Tapp E, Zenz M. Serum concentration of S-100 protein in assessment of cognitive dysfunction after general anesthesia in different types of surgery. Acta Anaesthesiol Scand. 2002;46(4):384-9.

45. Connolly ES Jr, Winfree CJ, Rampersad A, Sharma R, Mack WJ, Mocco J, Solomon RA, Todd G, Quest DO, Stern Y, Heyer EJ. Serum S100B protein levels are correlated with subclinical neurocognitive declines after carotid endarterectomy. Neurosurgery. 2001;49(5):1076-82; discussion 1082-3.

46. Anderson RE. No correlation between serum concentrations of S100B and cognitive function. Acta Anaesthesiol Scand. 2002;46(9): 1179 .

47. Schroeter ML, Abdul-Khalik H, Diefenbacher A, Blasig IE. S100B is increased in mood disorders and may be reduced by antidepressive treatment. Neuroreport. 2002;13(13):1675-8.

48. Machado-Vieira R, Schmidt AP, Avila TT, Kapczinski F, Soares JC, Souza DO, Portela LV. Increased cerebrospinal fluid levels of S100B protein in rat model of mania induced by ouabain. Life Sci. 2004;76(7):805-11.

49. Schmitt A, Bertsch T, Henning U, Tost H, Klimke A, Henn FA, Falkai P. Increased serum S100B in elderly, chronic schizophrenic patients: negative correlation with deficit symptoms. Schizophr Res. 2005;80(2-3):305-13. 